Proceedings of the Annual Conference of the Agricultural Extension Society of Nigeria

Number: Twenty-Fifth Annual Conference

Theme: Enhancing the Role of Public and Private Extension in Soil Conservation and Agricultural Productivity

Date: 28-29, July 2020

Venue: Usmanu Danfodiyo University, Sokoto, Nigeria

ISSN: 1595 - 1421.http://aesonnigeria.org/ConfProc . Email: editorinchief@aesonnigeria.org

\title{
Cassava and Vegetable Farming on Wet Land among Farmers in Ibaji Local Government Area, Kogi State, Nigeria
}

https://dx.doi.org/10.4314/jae.v25i1.4S

Paul A. H.

Department of Agricultural Economic and Extension, Faculty of Agriculture and Life Science Federal University Wukari Taraba State Nigeria. amadepaul.ap@gmail.com.

Phone no 08037468482

\section{Tikwe K. M.}

Department of Agricultural Extension and Management, college of Agriculture Jalingo Taraba State Nigeria

Nakwe S. H. G

Department of Crop Science, college of Agriculture Jalingo Taraba State Nigeria

\begin{abstract}
The study reviewed cassava and vegetable farming activities on wetland among farmers in Ibaji LGA Kogi State. Wetland can be defined as lands subject to excessive wetness, to the extent that the wet conditions influence the possible land uses. The wet soils in Kogi State exhibit similar physical, chemical and biological characteristics as do most or all soils in wetland ecologies. The textural composition of the wet soils in the study area varies widely from sand to clay loam with good physical properties. Data collected included information on farming season, social/infrastructures available in the area, major occupation of the people, major crop grown and others. Potentials of wetland soils include wetlands are seasonally or perennially wet and have ample water supply occur in level to gently sloping landscapes, are immune to the hazards of soil erosion. The soils are saturated 6 to 8 months of the year. Sources of information available to the farmers are through neighbours, friends and extension agents. Constraints to wetland land use are climatic (mainly rainfall), hydrological, soil, biological, and socio-economic factors. However, the major constraints to the cropping systems in the wet lowlands are abundance of water and its management, disease, pest and weed control. Wet land farming should be encouraged by all to reduce food insecurity in the study area. Stakeholders should encourage farmers by providing farming inputs all year round
\end{abstract}

Key Words: Cassava, vegetable farming, wetland, farmers

\section{Introduction}

Over the last decade, Nigeria's domestic production has consistently lagged behind national food demand. The increasing pattern of annual shortfall is a dangerous pointer to the fact the nation may be on the threshold of food insecurity (Obasi, 2018). It has been reported that about $60.8 \%$ Nigerians are malnourished (Food and Agricultural Organization 2019). According to Esobhawan (2020), Nigerians consume $9.3 \mathrm{gms}$ of animals' protein per person per day on against the 


\section{Proceedings of the Annual Conference of the Agricultural Extension Society of Nigeria}

Number: Twenty-Fifth Annual Conference

Theme: Enhancing the Role of Public and Private Extension in Soil Conservation and Agricultural Productivity

Date: 28-29, July 2020

Venue: Usmanu Danfodiyo University, Sokoto, Nigeria

ISSN: 1595 - 1421.http://aesonnigeria.org/ConfProc . Email: editorinchief@aesonnigeria.org

recommended minimum daily requirement of $34 \mathrm{gms}$. Many institutional programmes in agriculture have been undertaken to solve the food crisis and increase agricultural intensification in Nigeria. Some of these were the National Accelerated Food Production Programmes (NAFPP) in 1872, River Basin Development Authority (RBDA) in 1974, Operation Feed the Nation (OFN) in1976, Rural Integrated Agricultural Development Programme (ADP) in 1976, Green Revolution, (GR) in 1980. Many of these efforts failed, for various reasons, to provide enough food for the teeming population of the country. Some of the reasons include poor funding leading to poor performance of many of the institutional reforms, misapplication of funds, under-investment in the sector and multiple political considerations in otherwise technical agricultural issues (Aghanenu, 2015).

FADAMA projects represent a more recent approach of Federal Government to increase agricultural production in the country. The objectives of the FADAMA project include the provision of support for water management systems is low lying flood plains so that farming activities can go on, particularly in the season, improve output and enhance farmers' income (Onemolease and Omoregbee, 2015; FAO, 2019). The programme was implemented in phases. Phase 1 started in 1993 and ended in 1999, while Phase II commenced in January 2004 and ended in December 2009.

Despite the operation of the FADAMA scheme, doubts have been expressed about its income potential. While Adewumi et al. (2019) claimed that cassava and vegetable farming in a wetland is a profitable enterprise capable of raising farmers' livelihood. Aghanenu, 2015 raises objections to its economic prospect giving the peculiar problems associated with the system such as technical constraints in the areas of drilling and credit. For a successful implementation of FADAMA III, base line data such as level of response to technology, credit sources and acquisition, production constraints will be required by the government.

The prospect of FADAMA farming in the country generally will greatly depend on farmers' willingness to adopt recommended technologies as well as their access to capital/credit. Such technologies are capable of raising productivity and increasing farmer's income (Fabeku, B. B. and Faleyimu O. I. 2017 ). Past adoption studies have shown that farmers; response to agricultural technologies has been relatively slow or selectively (Ehinmowo O. O. et al, 2017).

The Nigeria government has identified irrigation farming as one of the strategies for agricultural development (URT 1997; URT 2001). Further, the World Summit on Sustainable Development (WSSD) in 2002 recognized the need for promoting agriculture through Integrated Water Resource Management (IWRM) (Honggen Zhu et al 2016). River Basins (RB) are potential sources of water for human life. The water available is important for agricultural development, maintaining the ecology of the basin and use for domestic purposes. River Basins are also very fertile because flooding which occurs frequently is associated with soil nutrient enrichment due to deposition and nutrient transformation processes (Simon G. S., John C. B. and Kate S. (2016). 


\section{Proceedings of the Annual Conference of the Agricultural Extension Society of Nigeria}

Number: Twenty-Fifth Annual Conference

Theme: Enhancing the Role of Public and Private Extension in Soil Conservation and Agricultural Productivity

Date: 28-29, July 2020

Venue: Usmanu Danfodiyo University, Sokoto, Nigeria

ISSN: 1595 - 1421.http://aesonnigeria.org/ConfProc . Email: editorinchief@aesonnigeria.org

Since the 1980 s to date, there have been a number of efforts in Nigeria to promote irrigation farming in River Basins in order to increase food security and alleviate poverty in the country. These efforts concentrated on large-scale irrigation schemes, which were often too mechanized and expensive for most Nigeria farmers. There is ample evidence that most of these schemes or projects failed partly due to their high management costs, low capacity to manage them and due related problems such as sedimentation and salinization (WLE, 2016).

Traditional irrigation that utilizes natural moisture or water from either natural springs or river diversions in Basins, has been increasingly practiced as a means of ensuring food security and income generation to smallholder farmers (Honggen Zhu et al 2016). This type of irrigation is the most important in Nigeria in terms of extent. Here the farmers' resources are limited and the individual schemes cover relatively small areas. It has been estimated that about 150,000 hectares could be categorized under this type of irrigation (Obasi, 2018). Aghanenu, 2015 have pointed out that traditional irrigation has emerged and shaped from detailed understanding of local conditions in response to changing socio-economic, political and ecological conditions. As pointed out by Honggen Zhu et al (2016) traditional irrigation is not just a static and timeless activity. Instead, it is a dynamic process that varies geographically, and where, irrigating communities are capable of assimilating and adapting outside knowledge and experiences to improve their own situation. Under traditional irrigation systems, water is normally obtained from low-cost, temporary or semi-permanent river diversion structures.

Wetland cultivation is now being emphasized (Sadeghi SH, Hazbavi Z, Harchegani MK 2016), to supplement the uplands where soil productivity and crop yields have declined due to severe accelerated erosion and degradation (FAO, 2019), accentuated by farmers mining the physical, chemical, and biological fertility of their soils (IITA, 2015). Wetlands, with a few exceptions, are potentially productive and suitable for intensive wet and dry land uses because of favorable soil water balance, long growing seasons, low soil erosion hazards, large land units with gentle to flat topography, and moderate to high fertility status, enhanced by the soils' hydromorphic processes than their adjacent upland neighbors (Ehinmowo OO, Adewale IF, Ojo SO. 2017). The lowlands are important in agricultural development, but much less information is available on them than on the upland ecosystems, which is a considerable impediment for their utilization and intensification on a sustainable basis. Obasi, (2018) described multiple roles of wetlands, with a focus on flood plains in dry areas, which sustain populations of human beings and wild species. Until recently, wetland farming has been less attractive because of the arduous task of land preparation, water management, weed control, and the limited repertoire of crops that can be grown (Ehinmowo OO, Adewale IF, Ojo SO. 2017). Moreover, considerable amount of ameliorating inputs are needed to guarantee their sustained cultivation (Aghanenu A. S. and Onemolease E. A. (2015). Wetlands, generally, are ignored or abandoned. Sina A. and Ulrike P. (2017) 


\section{Proceedings of the Annual Conference of the Agricultural Extension Society of Nigeria}

Number: Twenty-Fifth Annual Conference

Theme: Enhancing the Role of Public and Private Extension in Soil Conservation and Agricultural Productivity

Date: 28-29, July 2020

Venue: Usmanu Danfodiyo University, Sokoto, Nigeria

ISSN: 1595 - 1421.http://aesonnigeria.org/ConfProc . Email: editorinchief@aesonnigeria.org

classified wetlands as marginal lands, not necessarily because they are degraded but because of potential severe limitations to their use now.

Royal Haskoning DHV (2019) reported that in kogi State, upland farmland is finite in its availability together with rapid population growth. Loss of agricultural lands to other land-based enterprises is a major challenged of wetland cultivation in the state. Traditional land ownership system in which a man children inherit his land, has created a land use predicament for which there is no easy solution. They observed further that wetlands or swamplands on the other hand,are extensive in the state, are traditional sources of fishes, firewood, medicines, timber, construction materials and ropes, and wildlife. The wetlands are reputed to produce over $90 \%$ of crops grown on upland farms, and are therefore more important than the upland farm lands in that they can be used in the wet season (mainly rice), dry season (cassava, yams, coco yams, tomato, and vegetables), and all year round for tree crop production.

The wetlands thus form an important link in the economic system of the wetland areas in the State. Farmers in Kogi State having realized the profitability of wet, dry and all year land use in the swamplands, are, as in most other wetland environments, defying the odds to expand the production of tubers, roots, grains, fruits and vegetables to these hitherto neglected or under-utilized natural resource.

Haruna (2015) studied the prospects and problems of production under irrigation in FADAMA areas of Kogi State, Nigeria. The study sampled 120 vegetable farmers. Tools for data analysis used were descriptive statistics and Ginni Concentration Ratio (GRC). The result showed that the per capita land increased from 0.05 ha to 1.0ha for wetland farmers brought about a tremendous increase in the yield of vegetables from 1991 to 1999 . The vegetable growers also acquired many assets due to farming in the FADAMA areas. The important problems identified to be affecting vegetable production include inadequate credit, high cost of farm inputs and inadequate marking outlets among others.

Vegetables usually augment nutritive value of most of our staple food, which are deficient in vitamins, proteins and minerals. A remarkable change in nutritional requirements of an individual is bound to influence his health, skill and productivity. Now that the rural dwellers are finding it difficult to consume enough animal proteins, their dietary needs could be to some appreciable extent, met from the consumption of vegetables (IITA, 2017). A judicious mixture of different vegetable proteins is enough to meet our daily protein requirements. Vegetables are also a good source of oils, carbohydrates, minerals and vitamins. Despite the nutritional value of vegetable they are not accorded their appropriate uses in the diet of the West African peoples partly because of ignorance of nutritive value of these foods and largely due to cost, difficulty of storage and distribution (Abe, S. S., et al 2017). 
Proceedings of the Annual Conference of the Agricultural Extension Society of Nigeria

Number: Twenty-Fifth Annual Conference

Theme: Enhancing the Role of Public and Private Extension in Soil Conservation and Agricultural Productivity

Date: 28-29, July 2020

Venue: Usmanu Danfodiyo University, Sokoto, Nigeria

ISSN: 1595 - 1421.http://aesonnigeria.org/ConfProc . Email: editorinchief@aesonnigeria.org

\section{Methodology}

Kogi state has a total landmass and total population of about $30,345.74 \mathrm{Km} / \mathrm{Sq}$ and $3,442,868$ respectively. Specifically, it lies between latitudes $6049 " \mathrm{~N}-8030 " \mathrm{~N}$ and longitudes 5035"E - 7045"E.

Ibaji Local Government Area (LGA) of Kogi State has the headquarters at Onyedega. Ibaji LGA is situated between latitude $7^{\circ} 00^{\prime}-8^{\circ} 50^{\prime} \mathrm{N}$ and longitude $7^{\circ} 30^{\prime}-$ $8^{\circ} 00^{\prime} \mathrm{E}$. It has tens council wards with an estimated population of 127,572 people comprising 64,423males and 63,149females (National Population Commission (NPC), 2006). The council wards are grouped into three districts; Onyedega, Unale and Ujeh.

Data included information on the farming season, farmer's occupation, social and infrastructures, socio-economic factors, spatial distribution and pattern of socioeconomic development.

\section{Results and Discussion}

\section{General Characteristics of a Wetland}

A wetland can be defined as land subject to excessive wetness, to the extent that the wet conditions influence the possible land uses (Sadeghi SH, Hazbavi Z, Harchegani MK (2016).). Wetlands are characterized by the presence of wetland hydrology, hydrophytic vegetation, and hydric soils (Honggen Zhu et al 2016), and are complex ecosystems that are poorly understood relative to terrestrial and aquatic systems (Andrew H. B., et al. 2020). Wetlands are frequently transitional landscapes between terrestrial and aquatic systems and therefore possess characteristics of both. Wetlands function by serving as sinks, sources and transformers of nutrients and chemical contaminants (Havalend E. Steinmuller, Lisa G. Chambers (2019). Wetland or hydric soils are thus soils with water at or near the surface for most of the growing season or soils saturated long enough to support plants that grow well in wet environments. A wetland soil can be defined as soil with an aquic soil moisture regime (Soil Survey Staff, 1999). The water saturation originates from either groundwater or water of the capillary fringe for some part of the year. Wetland soils generally occur frequently as the lower portions of top sequences and where the soils exhibit remarkable heterogeneity in characteristics and therefore with varied potentials and limitations for increased food crop production. The occurrence of such soils is conditioned by hydrology, lithology, topographic position or physiography, and rainfall amount and distribution pattern.

The climate of Kogi State is tropical hot humid, characterized by distinct wet and dry seasons. For most of the State, the wet season lasts from April through October, that is, at least 8 months of concentrated rainfall. For instance, the mean annual rainfall received within the drainage basin, the central and main drainage system in the State, is $9624 \times 108 \mathrm{~m} 3$, the mean annual evaporation is less than one- 


\section{Proceedings of the Annual Conference of the Agricultural Extension Society of Nigeria}

Number: Twenty-Fifth Annual Conference

Theme: Enhancing the Role of Public and Private Extension in Soil Conservation and Agricultural Productivity

Date: 28-29, July 2020

Venue: Usmanu Danfodiyo University, Sokoto, Nigeria

ISSN: 1595 - 1421.http://aesonnigeria.org/ConfProc . Email: editorinchief@aesonnigeria.org

third that amount, thus leaving a water surplus of over $6586 \times 106 \mathrm{~m} 3$. The wet season thus favours the seasonal saturation of the soils with water and seasonal flooding of the vast areas of low-lying lands; Kogi State being mostly a flat to gentlelying sandy coastal area of low relief, contributing to the existence of the wetland or swampland areas. The swamplands in the State are therefore the result of a combination of a humid climate with a heavy concentration of rainfall and an abundance of low-lying land in the floodplains of the State.

Four vegetation and land use types within the wet lowland areas have been distinguished in the State. The sequence from the wetland to the drier up land is raffia forest, swamp forest, swamp grassland, and a mixture of swamp, dry season cropping and bush fallowing, usually occurring along the wetland fringe. Swamp forest covers $60 \%$, swamp grassland $20 \%$, and the remaining is the fringe land. Mixed farming is the rule, and a variety of staple crops is grown on the fringe (Haruna 2015)

\section{Physical and Chemical Characteristics of a Wetland}

The wet soils in Kogi State exhibit similar physical, chemical and biological characteristics as do most or all soils in wetland ecologies. The wetland and wetland soil literature is replete with excellent reviews of their soil quality attributes. The textural composition of the wet soils in the State vary widely from sand to clay loam reflecting the nature and spatial variability of the parent material of the soils, mainly, the Tertiary shale and sandstone in the north and north-east, the Quaternary coastal plain sands in the middle, and the fluvial marine beach sands in the south. The soils generally have good physical properties, for instance, easily workable, wet or dry season. Equally, the textural characteristics are not limiting to soil water availability since the groundwater and capillary fringe can supply the crop rooting zone adequately Sina A. and Ulrike P. 2017.

In their material nature, the soils, like their upland counterpart, occur in the recent geological sediments, and have immature or weakly developed and poorly expressed profile morphology. The soil characteristics are therefore determined by the nature of the parent material. The characteristics vary widely because of local geology and the degree of weathering occurring in the catchment. This may be the reason why soils in the north and north-east on shale and sandstone are finetextured to coarse-textured, while soils on coastal plain sands and fluvio-marine or alluvial sediments are coarse-textured Andrew H. B., et al 2020.

Although soils of the wetlands derive from their adjacent upland counterpart, wetland soils generally differ in clay mineralogy because of alluvium and neo-formation. The chemical fertility status is generally better than that of upland soils. 


\section{Proceedings of the Annual Conference of the Agricultural Extension Society of Nigeria}

Number: Twenty-Fifth Annual Conference

Theme: Enhancing the Role of Public and Private Extension in Soil Conservation and Agricultural Productivity

Date: 28-29, July 2020

Venue: Usmanu Danfodiyo University, Sokoto, Nigeria

ISSN: 1595 - 1421.http://aesonnigeria.org/ConfProc . Email: editorinchief@aesonnigeria.org

\section{Potentials of the Wetland Soils}

The wetlands, are seasonally or perennially wet and have ample water supply occur in level to gently sloping landscapes, are large that large-scale farming is feasible, and are immune to the hazards of soil erosion. The soils are saturated 6 to 8 months of the year. When water inputs from rainfall and overland flow exceed evapotranspiration (ET) and drainage, a favourable soil water balance develops, the excess rain water recharges the groundwater, causing a rise in the cyclical groundwater table. Aghanenu A. S. and Onemolease E. A. (2015), During the rain period, the water table is at or near the soil surface and flooding may occur varying in depth from a few centimeter to several meter deep, suggesting the prevalence of an aqua soil moisture regime, and a soil profile that is both hydromorphic and reducing. A high and shallow water table and flooding thus characterize the land-type during the rainy season, and naturally the main determinant of the potential land use. The result is that much of the wetlands are under fallow because of waterlogging and flooding.

In the dry season (November to March), higher thermal gradients develops, the evaporation zone moves to deeper layers in the profile, and the transition from the second to the third rate stages of soil evaporation drives the water table to lower depths. Consequently, the matric potential at the soil surface decreases, upward transport of soil water is reduced, soil water suction increases, the profile becomes oxidizing, changing from an aquic to an ustic soil water regime. Soil water content decreases, affecting the water balance of the rooting zone. The recession of the water table increases the crop rooting and water storage depths. However, the capillary fringe can supply the water lost to evaporation and crop water requirements. The seasonal fluctuation in the depth of the water table indicates the suitability of the wetlands and/or soils for wetland, dry land, and wetland/dry land utilization types. While wetland use implies adapting the farming of the landtype to the wet condition (Honggen Zhu et al (2016), for instance, mono-cropping the lands to swamp rice, dry land use means cultivating the lands to "dry foot" crops, that is, crop plants with aerobic edaphic requirements, e.g., cassava, maize and vegetables, as is now common in the area. In other words, the wetlands change from fluxial rice lands in the rainy season to dry land conditions following the recession of the groundwater table. The vast hectare of swamplands thus hold a great potential for increases in swamp rice and arable crop production and is the only resource to be used on a sustained basis.

Rainfall is adequate and well distributed, and flooding from river overflow and overland flow and ponding of long duration (3 to 5 months) are common. These hydrological processes are enhanced by the less permeable, medium textures of the sub-soil with excellent water retention characteristics, even though soil texture may be unimportant since sufficient water is always available. In other words, the ideal conditions for lowland swamp cassava exist, including favorable rooting depth and root development characteristics, medium fine to fine sandy loam over sandy clay loam texture, terrain of less than $1 \%$ slope, open space, swamp grassland 


\section{Proceedings of the Annual Conference of the Agricultural Extension Society of Nigeria}

Number: Twenty-Fifth Annual Conference

Theme: Enhancing the Role of Public and Private Extension in Soil Conservation and Agricultural Productivity

Date: 28-29, July 2020

Venue: Usmanu Danfodiyo University, Sokoto, Nigeria

ISSN: 1595 - 1421.http://aesonnigeria.org/ConfProc . Email: editorinchief@aesonnigeria.org

vegetation that can easily be cleared at minimum costs, and no runoff.

Consequently, the question of irrigation does not arise. Because of the close relationship between flooding and soil chemical fertility, such as the transport of significant amounts of suspended solids and nutrients, buffering the soil $\mathrm{pH}$ to near neutral, enhancing biological $\mathrm{N}$ fixation and carbon supply, and increasing diffusion rates, mass flow, and the availability of nutrients, the hydromorphic conditions which prevail in the wetland soils are excellent for the nutrition of the cassava and vegetable, as well as dry land crops. This will make the low resource farmers less dependent on "imported" chemical fertilizers. Moreover, and especially where the flood level can average 20 to $30 \mathrm{~cm}$, the less permeable sub-soil enhances ponding, which can be used to control weeds and soil erosion, and depress soil-borne plant diseases, in addition to fertility improvement (Ehinmowo OO, Adewale IF, Ojo SO. 2017) had shown that flooding made weeding unnecessary. However, better results, in terms of increases in yields, would be obtained when water control is consciously done taking into account knowledge of the ecology, economic and social environment.

When rainfall diminishes and is less than evapotranspiration (ET) level, and the flooding level or water table has receded, aided by favorable meteorological conditions (higher temperatures and atmospheric evaporability) and soil internal drainage, dry land conditions (mainly improved aeration and soil strength) prevail in the wet soils. The soils are then cultivated to "dry foot" crops and this is the practice by the smallholder farmers in the area. Since the period is the end of one flooding season and the apparent commencement of another, and in order to avert some disasters as much as possible, the farmers select their arable crops and plan their husbandry activities such that planting takes place as soon as flooding recedes, and soil strength improves, while harvesting is completed just before the onset of the succeeding flooding event. That is, early planting that enables crop roots to follow the capillary fringe of the receding water table.

The dry season interval is long enough to permit successful cultivation of shortseason or medium-season arable crops such as maize, cowpea, okra, melon, watermelon, water-leaf, pumpkin, garden egg, pepper and groundnut (Andrew H. B., et al. 2020). Long growing season crops such as yams and cassava are grown on mounds constructed by heaping the surface soil, but are usually harvested early $(7$ to 8 months) and immature to avoid damage or total crop loss due to flooding. This has proved lucrative in the area and is drawing attention to the potential productivity of the wet soils. Cropping is expanding beyond the area usually grown to rice. It is pertinent to state that tillage for rice production consists in inverting the surface soil, a form of minimum tillage, that favours the growth of roots of the subsequent upland crops. In other words, puddling, that drastically alters soil structure, is not practiced. Tillage, essentially, is to control weeds.

The cultivation of wetlands is integrated in the upland farming activities, and both are complementary. The cropping systems and the associated rotation adopted in wetland and upland farming reveal that the farmers have good 


\section{Proceedings of the Annual Conference of the Agricultural Extension Society of Nigeria}

Number: Twenty-Fifth Annual Conference

Theme: Enhancing the Role of Public and Private Extension in Soil Conservation and Agricultural Productivity

Date: 28-29, July 2020

Venue: Usmanu Danfodiyo University, Sokoto, Nigeria

ISSN: 1595 - 1421.http://aesonnigeria.org/ConfProc . Email: editorinchief@aesonnigeria.org

understanding of the climatic and edaphic conditions in these agroecosystems, and often utilize the diversity of their conditions to diversify their crops (Aghanenu, 2015), and to increase their productivity. Although much of the wetlands is under-utilized and even undeveloped, there is increasing consciousness about their productive capacity and are increasingly being exploited.

\section{Sources of Information on Cassava and Vegetable Wetland Farming by Rural Farmers}

One of the critical issues in the adoption of innovation is the role of information and seed exchange between farmers. Although the extension service has been the traditional channel through which seed is distributed to farmers, this variety has spread mainly through farmer-to-farmer horizontal diffusion. Survey results show that most farmers received information and first seed from other farmers in their villages. However, about $40 \%$ of farmers relied on direct purchases in the market for seed acquisition. In the villages, farmers' seed exchange network systems have become more important in varietal diffusion (Honggen Zhu et al 2016). This has made adoption rate slow in the state. The type of innovation decision is optional which can be affected by culture, values, norms and genuineness of the information. Ajala et al. (2015) in their work of assessing the effectiveness of improved cassava production technologies among cassava farmers revealed that $46.0 \%$ of cassava farmers had medium level of awareness of improved technologies, while $33.0 \%$ had high level of awareness. Over 65 percent of cassava farmers in the case study area are already farming on a wetland and according to Nsoanya and Nenna (2016) in their study, adoption of improved cassava production technologies revealed that majority of farmers $(60.0 \%)$ were aged between $31-40$ years, This is an advantage for the adoption and spreading of innovative practices since young people are likely to accept and serve better as agents of innovation transfer (Ogban, P. I. and Babalola, O. 2016.). Ekenta (2015) stated that, adoption of improved technologies is influenced by certain factors and is a function of farmer's characteristics, extension agency and the new technologies themselves as material components.

\section{Constraints of the Wetland Soils}

Constraints to wetland land use are climatic (mainly rainfall), hydrological, soil, biological, and socio-economic factors. However, the major constraints to the cropping systems in the wet lowlands are abundance of water and its management, weed, disease and pest control, and poor yielding crop varieties, especially cassava and vegetable (Havalend E. Steinmuller, Lisa G. Chambers (2019).. Rainfall is favorable but the excessive unpredictable seasonal deep flooding and the associated high groundwater level limit the exploitable area and directly affects the optimum uses of the wet soil resource. As already stated, flooding can be widespread and flood levels can range from tens of centimeter to several meter deep. Consequently, a small proportion of the considerable area of wetlands is cultivable Simon G. S., John C. B. and Kate S. (2016). Even where flood levels are relatively low, about $20 \mathrm{~cm}$, there is no conscious water control, no land leveling or bunding, 


\section{Proceedings of the Annual Conference of the Agricultural Extension Society of Nigeria}

Number: Twenty-Fifth Annual Conference

Theme: Enhancing the Role of Public and Private Extension in Soil Conservation and Agricultural Productivity

Date: 28-29, July 2020

Venue: Usmanu Danfodiyo University, Sokoto, Nigeria

ISSN: 1595 - 1421.http://aesonnigeria.org/ConfProc . Email: editorinchief@aesonnigeria.org

and what appears like bunds are ridges of slashed weeds deposited at plot boundaries, and which can easily decay or yield to the force of flowing water. Crop (cassava and vegetable growth) responds to excessive flooding is rapid elongation and lodging where the flood level fluctuates following short rainless periods. Under this condition, drainage is not a practicable solution as it requires costly major engineering works that would cover very large areas. The risk of crop loss to running water and submergence is therefore high.

It has been stated that flooding and waterlogging favour the nutrition of vegetable and cassava, because flooding alters the chemical and electrochemical processes and releases nutrient elements in wet soils, as well as prevent or minimize physiological disorders (Ekenta 2015). Water control (therefore) reduces the risk of soil erosion and loss of applied or native nutrients, increases availability of water and nutrients, and controls weeds, and inundation at critical periods can be prevented and excess water removed. Uncontrolled flooding water, on the other hand, is the major cause of the erosion of fine clay particles and organic matter, and loss of plant nutrients from the colloidal complex, and fixed $\mathrm{N}$. Consequently, lack of water management may be the single most important factor causing sustained low yields in wetland agriculture, besides low inherent fertility, and sweeping away of mineralized nutrients, in the area. Another factor of low yields is unimproved crops with low yielding potentials.

Besides the problem of low yielding varieties is iron toxicity evident in the wet soils. The adjacent upland soils are rich in iron, and during the rain period, iron is reduced and carried into the swamps via sub-surface water flow (Nsoanya, L. N. and Nenna, M.G. (2016). The level of reduced iron can reach very high concentrations in prolonged waterlogged soils and can adversely affect yield, even though rice vary in the degree of tolerance to iron toxicity. This problem is common in the north-east on shale and sandstone parent materials.

Wetlands are habitats for many debilitating or fatal human and animal diseases too, namely, Schistosomiasis (bilharzias), Onchoceriasis (river blindness), Dracunculiasis (guinea worm), Trypanosomiasis (sleeping sickness), and malaria, and are a deterrent to wetland farming, and explain why these lands are fallow during the rainy season, especially. Sina Ayanlade and Ulrike Proske (2017) reported that these are some of the reasons upland farming is preferred to wetland cultivation. The incidence of human disease is therefore more important than that of crop pests and diseases. Generally, farmers do not perceive the latter as a serious problem, and they do not have any means of controlling them. This is because although the insect pests and diseases are present, their damage usually does not reach economic levels in the traditional multiple cropping systems practiced (Honggen Zhu et al 2016).

Weed control is closely related to water management, and under improved management systems, flood level is usually manipulated to suppress weed growth. Weed suppression however depends on water delivery (through engineering works), 


\section{Proceedings of the Annual Conference of the Agricultural Extension Society of Nigeria}

Number: Twenty-Fifth Annual Conference

Theme: Enhancing the Role of Public and Private Extension in Soil Conservation and Agricultural Productivity

Date: 28-29, July 2020

Venue: Usmanu Danfodiyo University, Sokoto, Nigeria

ISSN: 1595 - 1421.http://aesonnigeria.org/ConfProc . Email: editorinchief@aesonnigeria.org

water retention (including bunding, leveling and puddling), and drainage (Ajala, A. O. et al (2016). Already there are no conscious water control structures, so that flood levels fluctuating according to the intensity of the torrential downpours, are favourable in some years and inadequate in others. Where rainfall is barely sufficient to maintain the water table at shallow depths above the soil surface, it may eliminate upland weed species, but competition from wetland weeds is fierce, and demand for labour is high, competing with upland farming F. A. O 2019.

In the dry season, the weed ecology on dry wet lands changes; vigorous growing noxious terrestrial weeds replace aquatic weeds. Weeds damage the yielding potential of the land. Weeds, not pests and diseases, are the most limiting factor for yields (Ajala, A. O.; Ogunjimi, S. I. and Farinde, A. J. (2016). Weed control in entirely manual, as a rule. Already, costs and timing of weeding, and shortage of labour impose severe strains on the farmers. It takes more than $50 \%$ of the time farmers spend on the field. Weed control is associated with drudgery that characterizes low resource agriculture. To reduce drudgery and maintain yields at high levels, weed growth and competition must be controlled by maintaining an environment that is detrimental to weeds. Chemical weed control is costly, besides the fact that the wet condition which prevails in the land-types enhances the breakdown of soil-applied herbicides. Mulch is a practice that can benefit both the soil and the farmer Aghanenu A. S. and Onemolease E. A. (2015). But mulching (to conserve soil water and suppress weed growth) may be delayed since it may hinder evaporability. This is because the transition from the wet soil condition to that during when soil strength would have improved may be slow and delayed due to the length of the preceding rain season, current evaporative demand, and soil profile conditions. Consequently, weeds would have grown profusely before the soil is dried that mulch could be applied, even as mulching is not a common agronomic practice in the farming systems in the area. Therefore, to control weeds and make wetland farming attractive, an effective weed management method that would alleviate the weed constraint and improve the productivity of both land and farmer, compatible with the traditional farming systems, is needed.

Under the low technology and fragmentary farming systems (wetland or upland agroecosystem), the smallholder farmers make decisions that are related to their agrosocio-economic and environmental circumstances (Nsoanya, L. N. and Nenna, M.G. (2016). The farms are also scattered and tenure is uncertain, support infrastructure are poor (that is, transport system with poor road network frequently impassable during the rainy season), high cost and low productivity of labour, and lack of credits, all compound the production constraints and sustain the low productive capacity of the smallholder farmers.

\section{Conclusion and Recommendations}

Wetlands are lands that are seasonally or perennially wet due to climate, physiography, lithology, and hydrology, and the wet conditions influence the possible land use. A wet soil on the other hand, is a soil that is saturated most or part of the 


\section{Proceedings of the Annual Conference of the Agricultural Extension Society of Nigeria}

Number: Twenty-Fifth Annual Conference

Theme: Enhancing the Role of Public and Private Extension in Soil Conservation and Agricultural Productivity

Date: 28-29, July 2020

Venue: Usmanu Danfodiyo University, Sokoto, Nigeria

ISSN: 1595 - 1421.http://aesonnigeria.org/ConfProc . Email: editorinchief@aesonnigeria.org

growing season, and can have a reducing profile. Considerable hectare of potentially productive wet soils occurs in Kogi State, but the soils are little studied, undeveloped, and under-utilized. The State experiences heavy concentrated rainfall that causes waterlogging and flooding on the vast area of flat to gently sloping lowlands. The seasonally wet lowlands are immune to soil erosion hazard, water is adequately available, and although chemical fertility is low, it is better than in the well-drained upland soils. The swamps can support the cultivation of cassava and vegetable and dry land crops in wet and dry season profitably. Debilitating human and animal diseases, plant pests and diseases, weeds and lack of water control are limiting factors to increasing agricultural production in the wet lands. Management practices to alleviate these constraints to optimize the uses of the wet land-types include water control and chemical fertility management especially for dry season production.

The extension agent needs to do more in the area of awareness creation among the farmers. Stakeholders should encourage farmers by providing farming inputs all year round. Extension agents should encourage the farmers to form cooperative society to enable them benefits from the government.

\section{References}

Abe, S. S., Buri, M. M., Isaka, R. N., Kieppe, P. Wakatsuki, T. (2017). Development of Affri-innovation for agriculture. Forestry and Fisheries 44(4): 343-355.

Aghanenu A. S. and Onemolease E. A. (2015). Farmers' Response to the Application of Modern Technologies to Wetland Farming in Edo State, Nigeria

Ajala, A. O.; Ogunjimi, S. I. and Farinde, A. J. (2016). Assessing the effectiveness of improved cassava production technologies among cassava farmers in Osun state, Nigeria. Wudpecker Journal of Agricultural Research: 1 (7), 281 - 288. http://www.wudpeckerresearchjournals.org

Andrew H. B., Kate B., Margaret P., Stephanie Y. (2020). The role of organic amendments in wetland restorations Restoration Ecology: the journal of the society for ecological restoration 19 April 2020 https://doi.org/10.1111/rec. 13179

Ehinmowo OO, Adewale IF, Ojo SO. (2017) Empirical analysis of poverty status of small scale cassava processors in Nigeria. Journal of Agricultural Faculty of Gaziosmanpasa University. 2017;34(1):26-32.

Ekenta, C. (2013). Factors Associated with Adoption of Recommended Soyabeans Production in Markarfi L.G.A. of Kaduna State. Msc Thesis, Ahmadu Bello University, Zaria

Esobhawan A.O. and Alabi R. A. 2020. Analysis of income sources of women farmers in rural areas of Delta state, Nigeria. Global Approaches to Extension Practice Vol. 3 (1) 2007: pp. 66-71

Fabeku, B. B; Faleyimu O. I (2017). Drought impact assessment on vegetation over Sudano-Sahelian Part of Nigeria J. Appl. Sci. Environ. Manage. October 2017 Vol. $21(6)$ 
Proceedings of the Annual Conference of the Agricultural Extension Society of Nigeria

Number: Twenty-Fifth Annual Conference

Theme: Enhancing the Role of Public and Private Extension in Soil Conservation and Agricultural Productivity

Date: 28-29, July 2020

Venue: Usmanu Danfodiyo University, Sokoto, Nigeria

ISSN: 1595 - 1421.http://aesonnigeria.org/ConfProc . Email: editorinchief@aesonnigeria.org

F A O 2019. The State of Food and Agriculture 2019 Moving forward on food loss and waste reduction Rome. Licence: CC BY-NC-SA 3.0 IGO

Havalend E. Steinmuller, Lisa G. Chambers (2019). Characterization of coastal wetland soil organic matter: Implications for wetland submergence: Science of the Total Environment pg648-659 journal homepage: www.elsevier.com/locate/scitotenv

Honggen Z, Zhengfei G. and Xuan W. (2016) Factors Influencing Farmers' Willingness to Participate in Wetland Restoration: Evidence from China

International Institute of Tropical Agrculture (IITA) Cassava Oyo, Ibadan: CGIAR; 2015. Available: http://www.iita.org/cassava

Karin M. Kettenring, Emily E. Tarsa, Need to Seed? Ecological, Genetic, and Evolutionary Keys to Seed-Based Wetland Restoration, Frontiers in Environmental Science, 10.3389/fenvs.2020.00109, 8, (2020).

Kogi state M.D.Gs and multilateral UN millennium developmental goals, 2008.

Kogi State Government profile, 1992. Official website of Kogi state government of Nigeria: Available at:www.kogistatenigeria.org/solid_minerals.htm (4/01/12).

National Population Commission (NPC), Nigerian population census 2006 analysis, 2006

Nsoanya, L. N. and Nenna, M.G. (2016). Adoption of improved cassava production technologies in Anambra-East Local Government Area of Anambra State, Nigeria. Journal of Research for International Development: 9 (2), 36-43. www.ajol.info/journals/jorind

Obasi P. C, Henri-Ukoha O. N, Anosike, Ibekwe U. C. (2015). Net returns to cassava -based crop mixtures in Imo state, Nigeria. European Journal of Agriculture and Forestry Research. 2015;3(1):15-21.

Obasi, P. N. Esom, N. E. Okolo, C. M. Edene E. N. (2018). Assessment of water pollution status in the mining area of Ameka, South Eastern Nigeria using metal Pollution Index. Volume 2, Issue 1, pp. 66-73, 2018.

Ogban, P. I. and Babalola, O. 2016. Characteristics, classification, and management of inland valley bottom soils for crop production in sub-humid southwestern

Nigeria. Agro-Sci. J. Trop. Agric., Food, Environment and Extension 8(1): 1-13.

Omoregbee F. E., Awhareno U. S., Ekpebu I. D. (2015). Empirical analysis of cassava farmers socio - economic characteristics and their access to agricultural information in Delta State, Nigeria. IOSR Journal of Humanities and Social Science. 2015;9(1):11-18.

Sadeghi SH, Hazbavi Z, Harchegani MK (2016). Controllability of runoff and soil loss from small plots treated by vinasseproducted biochar. Sci Total Environ. 15(541):483-490.

Sadibo, WB and Jacob, AA. The making of Nigeria: Nigerbenue confluence. A publication of the National Commission for Museums and Monuments, Nigeria. 2006; 20-23.

Shifiona TK, Dongyang W, Zhiguan H (2016). Analysis of Namibian main crops annual production, consumption and trade-maize and millet. J. Agric. Sci. 8:7077. 
Proceedings of the Annual Conference of the Agricultural Extension Society of Nigeria

Number: Twenty-Fifth Annual Conference

Theme: Enhancing the Role of Public and Private Extension in Soil Conservation and Agricultural Productivity

Date: 28-29, July 2020

Venue: Usmanu Danfodiyo University, Sokoto, Nigeria

ISSN: 1595 - 1421.http://aesonnigeria.org/ConfProc . Email: editorinchief@aesonnigeria.org

Simon G. S., John C. B. and Kate S. (2016) Farmer perceptions of wetlands and water-bodies: Using social metrics as an alternative to ecosystem service valuation June 2016 Ecological Economics 126:58-69 DOI: 10.1016/j.ecolecon.2016.04.002

Sina Ayanlade and Ulrike Proske 2017 Assessing wetland degradation and loss of ecosystem services in the Niger Delta, Nigeria August 2015 Marine and Freshwater Research accepted DOI: 10.1071/MF15066

Temitope A. Laniyan and Adeniyi J. Adewumi (2019) Health Risk assessment of heavy metal pollution in groundwater around an exposed dumpsite in Southwestern Nigeria. Journal of Health and Pollution: December 2019, Vol. 9, No. 24, 191210.

WLE (2016). Guideline for Sustainable Management of Wetlands in Ihemi Cluster. Life land Project 